\section{Systematisk og personlig om atrieflimmer}

Dag Thelle, Maja-Lisa Løchen

\section{Kaotiske hjerter}

Atrieflimmer, en moderne epidemi. 225 s, tab, ill. Oslo: Gyldendal Akademisk, 2010. Pris NOK 375

ISBN 978-82-05-40543-1

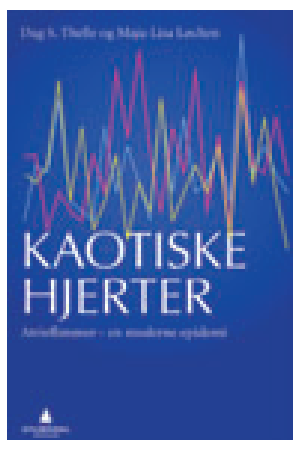

To epidemiologer begge med atrieflimmer - har skrevet om denne lidelsen som rammer mange og stadig flere. Forfatterne er begge kjent som gode formidlere. I denne boken viser de igjen på en utmerket måte denne evnen. Det

faglige innholdet er solid, og oppbyggingen er oversiktlig og pedagogisk god.

Målgruppene er mange. Boken er nyttig for helsepersonell, og den vil være av stor interesse for pasienter. Det er fire hoveddeler som er bygd opp slik at de kan leses selvstendig. I første del gir forfatterne en innføring i hjerterytmens fysiologi. Her forklarer de en rekke begreper på en lettfattelig måte, slik at også lesere uten spesiell medisinsk forkunnskap kan forstå det meste. Enkle illustrasjoner og korte tabeller øker tilgjengeligheten.

Den andre delen omhandler epidemiologiske forhold ved atrieflimmer. Her er forfatterne definitivt på hjemmebane. De går grundig til verks i å definere ulike epidemiologiske begreper, lenger enn det man forventer å finne i en bok om atrieflimmer. Det er en systematisk gjennomgang av den kunnskapen vi har om risikofaktorer, med en solid drøfting av hva faktorer som fysisk aktivitet, overvekt, alkohol, røyking, kaffe og stress utgjør av risiko for atrieflimmer. Man skal lete lenge etter en mer grundig og kvalifisert gjennomgang av disse viktige problemstillingene.

I tredje del presenterer forfatterne ni pasienthistorier, hvorav to er forfatternes egne. Denne delen har to hovedeffekter. Det kommer tydelig frem hvordan livskvaliteten påvirkes hos pasienter med atrieflimmer, og historiene viser hvordan flere av pasientene har opplevd lite tilfredsstillende møter med helsevesenet. Dette er tankevekkende.
Pasienthistoriene er direkte og ærlige og fremstår som de aller viktigste illustrasjonene.

I den siste delen går Thelle og Løchen grundig gjennom de terapeutiske utfordringene ved atrieflimmer. Igjen er oversikten systematisk og god, og de viktigste vitenskapelige arbeidene innen feltet refereres. De gir en kortfattet og oppdatert oversikt over aktuelle antiarytmika og retningslinjer for antikoagulasjonsbehandling. Det er også en god gjennomgang og beskrivelse av ablasjonsbehandling.

Personlig har jeg hatt stor glede og nytte av å lese denne boken. Man får en lett tilgjengelig oversikt over mye medisinsk faktakunnskap om en viktig sykdomstilstand. Pasienthistoriene sørger for en ekstra dimensjon. Boken vil være nyttig lesning for medisinstudenten og elektrofysiologen, for allmennpraktikeren, for sykepleieren og for pasienten. Med de behovene vi har, for å bedre tilbudet til denne pasientgruppen, vil dette være nyttig lesning også for helsevesenets beslutningstakere.

\section{Rune Wiseth}

Klinikk for hjertemedisin

St. Olavs hospital

\section{Komplett, revidert norsk lærebok i obstetrikk og gynekologi}

Per Bergsjø, Jan Martin Maltau,

Kåre Molne et al, red.

Obstetrikk og gynekologi

2. utg. 472 s, tab, ill. Oslo: Gyldendal

Akademisk, 2010. Pris NOK 749

ISBN 978-82-05-39911-2

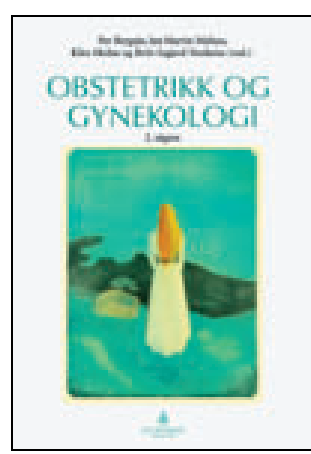

Redaktørene i denne andre utgaven av Gynekologi og obstetrikk er nåværende eller tidligere professorer ved Norges fire universiteter med medisinstudentundervisning. De har, sammen med 21 medforfattere,

oppdatert den første norske samlede læreboken på dette fagområdet fra 2004. Den følger samme lest og kapittelinndeling som førsteutgaven.

Målgruppen er medisinstudenter og leger, og boken er godt egnet for dette formålet. Jeg er også enig i redaktørenes egen vurdering om at «deler av stoffet vil være nyttig for jordmorstudenter og jordmødre, sykepleiere og annet interessert helsepersonell». Selv om medisinstudentene har et stort utvalg av internasjonale lærebøker å velge mellom, har denne læreboken en rekke fordeler for dem som vil jobbe i Norge. Læreboken er komplett og omfatter alle (for meg) tenkelige arbeidsområder og problemstillinger innen fagområdet. Ved siden av de tradisjonelle kapitlene om fysiologi, anatomi, graviditet, fødsel og gynekologiske sykdommer, inneholder boken mange kapitler man ikke kan finne i andre lands lærebøker; inkludert et historisk kapittel om den norske utviklingen av faget, norsk fødselsepidemiologi, lovverk og erstatningsordninger.

Flere av kapitlene har begrenset forslag til utfyllende lesning som er tilpasset hovedmålgruppen. Jeg kunne ønsket noen flere nettreferanser for ressursdatabaser. Boken er for summarisk til at den egner seg som lærebok i spesialistopplæringen i faget, men den er fin som en repetisjons- og oppdateringsbok, også for spesialister i fagområdet.

Min lille kritikk er at redaktørene i enda større grad kunne samordnet detaljer mellom kapitlene. Et eksempel er anbefalingene fra de to erfarne gynekologiske onkologene om at «cervix bør inspiseres minst en gang tidlig i svangerskapet, og cytologisk prøve tas hvis dette ikke er gjort i løpet av de siste tre årene» (s. 348). Denne anbefalingen, som antakelig følges av mange leger, er ikke i overensstemmelse med oversikt over svangerskapskontrollers innhold gitt i tabell 8.2 (s. 133) og teksten «Gynekologisk undersøkelse er ikke obligatorisk, gjøres etter klinisk skjønn. Cytologisk prøve tas bare ved mistanke om patologi» (s. 135). En annen inkonsistens er definisjonen på menopause, som oppgis som seks måneder blødningsfrihet ett sted (s. 110), mot 12 måneder andre steder (s. $287 \mathrm{og} \mathrm{s.} \mathrm{381).}$ De norske folatanbefalingene oppgis dessverre stykkevis og delt (for lavrisiko- versus høyrisikograviditeter i forhold til risiko for å utvikle nevralrørsdefekter), men aldri komplett $i$ ett av kapitlene. I tillegg er det antakelig forvirrende for studentene at «folat» og «folsyre»-ordene brukes om 
hverandre, selv om begge ordene er korrekte på norsk i denne sammenhengen.

Per Bergsjø døde dessverre nylig, og boken er et flott minnesmerke over en av nestorene i faget i Norge. Jeg koste meg med denne lettleste læreboken og anbefaler den gjerne til andre leger.

\section{Annetine Staff}

Kvinne- og barneklinikken

Oslo universitetssykehus, Ullevål

\section{Musikk som verktøy}

Even Ruud, red.

\section{Musikk i psykisk helsearbeid} med barn og unge

205 s, ill. Oslo: Norges Musikkhøgskole (NMH Skriftserie), 2010. Pris NOK 300 ISBN 978-82-7853-060-3

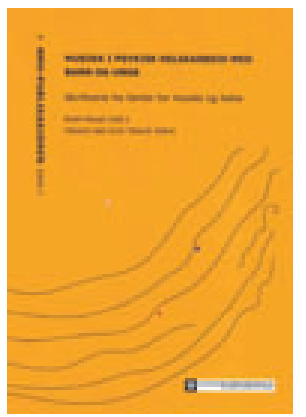

Denne antologien omhandler musikk i psykisk helsearbeid og er del av en skriftserie om musikk og helse. Even Ruud har satt sammen en variert artikkelsamling om bruken av musikk i psykisk helsearbeid med barn og unge, med hovedvekt på bruk av musikkterapi. Målgruppen er ikke definert, men ut fra formen går jeg ut fra at verket primært er rettet mot aktuelle faggrupper.

Derfor må profileringen av musikk som terapeutisk virkemiddel til fagmiljøer som arbeider med barn og unge, vektlegges i vurderingen av antologien. I motsetning til en del tidligere musikkterapilitteratur, som ga liten innsikt i hva som faktisk skjer i en musikkterapitime, er det i de senere årene utviklet en sterk deskriptiv tradisjon som gjør det lettere for utenforstående å forstå hvordan terapeuten arbeider. De levende beskrivelsene av musikalske samhandlinger er denne artikkelsamlingens store styrke. Samtidig er det tydelig at musikkterapiens tradisjonelle tilknytning til spesialpedagogikk og psykologi er vektlagt, selv om flere av forfatterne arbeider innen helsevesenets rammer. Blant hundretalls referanser fant jeg kun to som refererer til helsevesenets dokumentasjonskrav og vurdering av hva som virker. Integreringen av musikkterapi i et faglig team blir nokså kursorisk berørt, likeledes spørsmålet om hvordan de ulike terapeutiske metodene virker inn på hverandre og påvirker «sluttsummen av virkning» på en pasient. Den raskt voksende faglitteraturen fra medisinsk vinklet musikkterapeutisk psykisk helsearbeid med barn og unge glimrer med sitt fravær.

Forfatterne styrker forståelsen av hvor viktig musikk er for mennesker i hverdagen for å regulere følelser, styrke kommunikasjon og bygge identitet hos utsatte grupper, og de gir en ny forståelse av hvordan praksis bygges opp. Samtidig gir de få føringer for faglig integrering av musikkterapi i psykisk helsevern. Jeg håper derfor at et senere skrift fra samme senter kan inkludere medisinske perspektiver og faglitteraturen som presenterer musikk også i helsevesenets rammer. Jeg håper også at musikkterapeutiske verker som beveger seg innen helsevesenets rammer, i fremtiden viser større interesse for helsevesenets vektlegging av evaluering av effekt, slik at faglig dialog rundt terapeutisk bruk av musikk for utsatte grupper kan utvikle musikk til et stadig mer presist terapeutisk verktøy innen psykiatri og psykisk helsevern. Tross de manglene jeg har påpekt, gir denne artikkelsamlingen et viktig bidrag til den voksende faglitteraturen om musikkterapiens muligheter som supplerende behandlingstiltak.

\section{Audun Myskja \\ Senter for livshjelp Ski}

\section{Solid om deltakende observasjon}

Katrine Fangen

\section{Deltakende observasjon}

2. utg. 300 s. Bergen: Fagbokforlaget, 2010. Pris NOK 399

ISBN-978-82-450-1001-5

Læreboken Deltakende observasjon foreligger i ny og utvidet utgave. Forfatteren, Katrine Fangen, er sosiolog med bred forskningsbakgrunn. Hun er tilknyttet Universitetet i Oslo og leder et større EU-prosjekt om inkludering og ekskludering av innvandrere i Europa. Målgruppen er studenter, stipendiater og forskere som benytter deltakende observasjon som forskningsmetode. Deltakende observasjon, også kalt etnografi, assosieres gjerne med fag som antropologi og sosiologi, men innen medisin er det en økende interesse for metoden (1). Et overordnet formål med deltakende observasjon er å studere og beskrive hva individer sier og gjør i sammenhenger som ikke er strukturert og styrt av forskeren.

Gjennom de 14 kapitlene introduserer forfatteren metoden og dens historiske utvikling og går gjennom praktiske tips, etiske problemstillinger og spørsmål knyttet til analyse av observasjonsdata og publisering. Teksten er godt forankret i kilder, noe som gjør at den ikke blir en oppskriftsbok, men en tekst som innbyr til refleksjon. Fangen er teoretisk bredt orientert og gjør det tydelig for leseren at deltakende obser- vasjon er i utvikling og rommer ulike retninger. I tråd med dette er det lagt til omtaler, bl.a. av webetnografi og forskning med basis i ulike lokaliteter. Teksten byr på en rekke illustrerende eksempler fra Fangens egne og andre forskeres studier. Hvis man leser fra perm til perm, blir det en del repetisjon av hva disse eksemplene dreier seg om. Kanskje det hadde vært en idé å presentere kjerneeksemplene i noe mer fylde i innledningen? En ting må rettes opp i senere utgaver: REK betyr ikke «Rådet for medisinsk etikk» (s. 192), men står for «Regionale komiteer for medisinsk og helsefaglig forskningsetikk».

Deltakende observasjon er velskrevet og oppdatert. Leseren får en solid innføring i deltakende observasjon som forskningsmetode. Deltakende observasjon er krevende og stiller store krav til forskeren, og Katrine Fangen evner å fremstille metodens muligheter og utfordringer på en god og instruktiv måte. Det er mye å lære om kvalitativ forskning generelt, og jeg anbefaler derfor boken til alle som planlegger eller som gjennomfører kvalitative forskningsprosjekter innen medisin og helsefag.

\section{Jan C. Frich}

Avdeling for helseledelse og helseøkonomi Insitutt for helse og samfunn Universitetet i Oslo

\section{Litteratur \\ 1. Reeves S, Kuper A, Hodges BD. Qualitative research methodologies: ethnography. BMJ 2008 337: a1020}

\section{Funksjonshemning, sårbarhet og den psykoanalytiske annerledesheten}

Julia Kristeva, Eivind Engebretsen, red. Annerledeshet

Sårbarhetens språk og politikk. 293 s, tab, ill. Oslo: Gyldendal Akademisk, 2010. Pris NOK 389 ISBN 978-82-05-40078-8

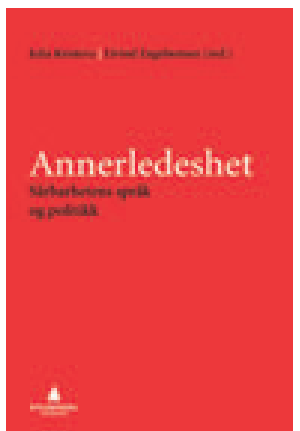

Den bulgarskfranske intellektuelle Julia Kristeva har ledet Det nasjonale råd for funksjonshemning i Frankrike og ble tildelt Holbergprisen i 2004 . Det danner bakgrunnen for at to av hennes tekster innleder en bok om funksjonshemning og annerledeshet på norsk.

Forfatterne av de 11 norske bidragene anvender og reflekterer over Kristevas perspektiver på en rekke konkrete områder, som 